\title{
PERSEPSI MASYARAKAT TERHADAP LINGKUNGAN KANDANG SAPI DI KELURAHAN BENER KECAMATAN TEGALREJO YOGYAKARTA
}

\author{
Vidyana Arsanti \\ Masuk: 16042018 / Diterima: 28062018 / Dipublikasi: 30062018 \\ (c) 2018 Fakultas Hukum dan IImu Sosial UNDIKSHA dan IGI
}

\begin{abstract}
Some activities involved in the cowshed can certainly not be separated from a thing called waste. It should be highly concerned the best way to manage the waste effectivelyfor the cowshed workers. The data processed by the researcher is categorized as Primary Data i.e. data collection by using questionnaires and interview technique. Meanwhile the Secondary Data was held by collecting data in the forms of documentations and observation. The research was executed in the cowshed existence reviewing context in order to discover people's perception affected by the existence of cowshed and cowshed workers activities in cultivating waste to decrease the environment contamination effects. The results of this research are (1) People's perception living around the cowshed location managed by the cowshed group named Tri AndiniRejo have neutral response, (2) The waste management done so far by the cowshed workers have some switches where they merely amassed and soldthe waste before to processing waste into quality and highly economic organic fertilizers. The Waste management with advanced technology has not been utilized properly by the cowshed workers due to the lack of Human Resources quality.
\end{abstract}

Key words: Cowshed; Waste Management; People's Perception

Abstrak Kegiatan yang berkaitan dengan kandang sapi tentunya tidak lepas dari apa yang disebut dengan limbah. Hal ini juga harus diperhatikan cara limbah ini dikelola dengan baik oleh pengelola kandang sapi dengan tepat manfaat. Data yang digunakan oleh peneliti yaitu Data primer yaitu pengumpulan data dengan kuesioner dan teknik wawancara, Data Sekunder yaitu pengumpulan data dengan dokumentasi dan observasi. Penelitian dilakukan dalam konteks mengkaji keberadaan kandang sapi dengan tujuan untuk mengetahui persepsi masyarakat terpengaruh dengan keberadaan kandang sapi dan aktifitas pengelola kandang dalam pengolahan limbah guna mengurangi dampak pencemaran lingkungan. Hasil dari penelitian ini (1) Persepsi masyarakat yang tinggal di sekitar lokasi kandang sapi yang dikelola oleh kelompok kandang Tri Andini Rejo memiliki respon netral, (2) Pengelolaan Limbah yang selama ini dilakukan oleh pengelola kandang memiliki pergeseran dari yang semula hanya menumpuk kotoran sapi kemudian di jual, sekarang diproses menjadi pupuk organik yang berkualitas dan bernilai ekonomi tinggi. Pengelolaan Limbah dengan menggunakan teknologi yang maju belum termanfaatkan dengan baik oleh pengelola kandang karena kurangnya kualitas Sumberdaya Manusia.

Kata kunci : Kandang Sapi; Pengolahan Limbah; Persepsi Masyarakat

\section{Pendahuluan}

Daging dan susu sapi merupakan kebutuhan utama yang penting, dimana daging dan susu sapi merupakan salah satu sumber protein hewani yang juga diperlukan oleh tubuh. Sehingga bahan baku daging dan susu sapi memiliki peran

Vidyana Arsanti

Universitas Amikom

Yogyakarta

vdya.ar@amikom.ac.id penting dalam menjaga kualitas dan kuantitasnya. Dengan adanya pengusaha ternak sapi maka diharapkan mampu memberikan suplay atau pasokan dari kebutuhan daging dan susu. Pengusaha atau peternak sapi tentunya tidak lepas dari adanya kandang sapi. Akan tetapi kendala yang dialami adalah bagaimana keberadaan kandang sapi ini di tengahtengah lingkungan masyarakat. Oleh karena itu, penting adanya kajian atau analisis yang berkenaan dengan 
lingkungan di sekitar keberadaan kandang sapi tersebut. Analisis lingkungan ini melibatkan masyarakat sebagai tolak ukurnya, tentunya analisis ini mengetahui keadaan lingkungan sebelum dan sesudah kandang sapi itu ada. Dari situ akan terlihat rona lingkungan yang berubah di sekitar keberadaan kandang sapi. Kegiatan yang berkaitan dengan kandang sapi tentunya tidak lepas dari apa yang disebut dengan limbah. Tentunya hal ini juga harus diperhatikan bagaimana caranya limbah ini dikelola dengan baik oleh pengelola kandang sapi. Oleh sebab itu, cara pengelolaan limbah yang sudah dilakukan oleh pengelola kandang harus diketahui apakah sudah tepat manfaat atau belum. Tepat manfaat disini yaitu bagaimana cara pengelolaan limbah tersebut agar limbah dari kandang sapi ini jika diolah dengan tepat maka akan dapat memperoleh manfaatnya. Hal ini merupakan alasan mengapa penelitian ini dilakukan di Kelurahan Bener Kecamatan Tegalrejo. Letak atau lokasi kandang yang berada di tengah-tengah permukiman penduduk tentunya menjadi kajian yang menarik untuk diteliti dengan mementingkan aspek lingkungan sekitar dan pengelolaan limbah tepat manfaat.

Jika pengelola kandang sapi tidak mengolah limbah sapi dengan tepat manfaat dan dibuang ke sungai karena lokasi kandang sapi berada di tepi sungai, tentunya hal ini dapat menyebabkan pencemaran air dan merusak lingkungan ekosistem biota air yang hidup di dalamnya (Luthfi \& Wijaya, 2011). Di sisi lain, jika pengelola kandang sapi tidak mengolah limbah sapi dengan tepat manfaat karena kandang sapi yang berada di tengah permukiman penduduk, maka hal ini dapat mempengaruhi kehidupan masyarakatnya misalnya yang pertama dari segi kenyamanan udara yang bersih dengan bau yang tidak sedap dan yang kedua adalah segi kesehatannya misalnya dengan banyaknya kotoran sapi pasti terdapat banyak lalat yang hinggap dan dapat menyebabkan penyakit diare (Soesanto, 2003). Kandang sapi yang ada di Kelurahan Bener Kecamatan Tegalrejo merupakan usaha ternak sapi yang hanya dikelola dengan skala kecil. Hal ini menimbulkan respon masyarakat dan pandangan masyarakat yang berbedabeda baik positif maupun negatif. Kondisi ini membuat peneliti tertarik untuk melakukan penelitian tentang analisis lingkungan di sekitar lokasi kandang sapi dan menawarkan solusi perbaikan kondisi lingkungan dengan memberikan masukan kepada pengelola kandang sapi dan perbaikan pengelolaan limbah kandang sapi.

\section{Metode}

Data yang digunakan yaitu data primer dan data sekunder. Data primer yang dikumpulkan yaitu persepsi masyarakat yang tinggal di sekitar kandang sapi tentang pengaruh kandang sapi terhadap lingkungannya dan mengumpulkan informasi tentang pengolahan limbah yang sudah dilakukan oleh pengelola kandang beserta permasalahannya. Pengumpulan data primer dilakukan dengan kuesioner dan panduan wawancara. Kuesioner digunakan kepada responden masyarakat yang tinggal di sekitar lokasi kandang Sapi, sedangkan panduan wawancara digunakan kepada responden pengelola kandang sapi.

Data sekunder dilakukan dengan dokumentasi dan observasi. Dokumentasi yaitu mencari data mengenai hal-hal yang berupa catatan-catatan (Arikunto, 2006). Dokumentasi adalah memanfaatkan dokumen yang sudah ada, misalnya peraturan pemerintah yang berkaitan dengan peraturan atau tata cara yang sudah tertulis berkaitan dengan pemeliharaan hewan ternak sapi dan juga aspek lingkungannya. Selain itu studi literatur yang sudah ada baik berupa 
buku-buku, Koran, dokumen-dokumen tertentu, majalah, atau media cetak maupun elektronik lainnya. Sedangkan observasi adalah pengamatan kualitatif secara langsung oleh peneliti untuk mengambil data-data berdasarkan kondisi di lokasi penelitian (Ariola, 2006). Peneliti mencatat dan mendiskripsikan tingkah laku masyarakat di lokasi sekitar kandang sapi.

Analisis data adalah langkah selanjutnya untuk mengelola data dimana data yang diperoleh, dikerjakan dan dimanfaatkan sedemikian rupa dan menyimpulkan persoalan yang diajukan dalam menyusun hasil penelitian. Analisis data pada dasarnya adalah proses menyederhanakan data yang diperoleh ke dalam bentuk yang lebih mudah dibaca dan dimengerti yang bertujuan untuk mendapatkan informasi yang lebih sederhana yang dapat digunakan untuk mencari makna dan implikasi yang lebih luas dari hasil-hasil penelitian (Sugiyono, 2007). Analisis yang dilakukan menggunakan penelitian kualitatif melalui proses data reduksi, data display, dan verifikasi dengan langkah-langkah:

a. Reduksi data, data yang dikumpulkan dirinci secara sistematis. Lalu untuk dapat dianalisis maka sebelumnya direduksi, yakni dengan memilih hal-hal pokok yang sesuai dengan fokus penelitian. Data yang telah direduksi memberikan gambaran yang lebih jelas tentang hasil pengamatan.

b. Penyajian data (data display). Peneliti mengembangkan sebuah deskripsi informasi tersusun untuk menarik kesimpulan dan pengambilan tindakan. Display data atau penyajian data yang lazim digunakan pada langkah ini adalah dalam bentuk teks naratif.

c. Penarikan kesimpulan dan Verifikasi, Verifikasi dapat dilakukan dengan syarat yaitu dengan cara mengumpulkan data baru. Laporan penelitian kualitatif harus memiliki persyaratan validitas, rehabilitas, realibilitas dan obyektivitas (Sujarweni, 2014).

d. Pengujian keabsahan data, dalam pengujian keabsahan data peneliti akan menggunakan metode FGD (Forum Group Discussion). FGD (Forum Group Discussion), adalah diskusi terfokus dari suatu kelompok untuk membahas masalah lingkungan yang ada di Kelurahan Bener Kecamatan Tegalrejo berkaitan dengan adanya kandang sapi yang terletak di tengah-tengah permukiman masyarakat. Jumlah pesertanya bervariasi antara 8-12 orang, dilaksanakan dengan panduan seorang moderator. Tujuan diskusi kelompok ini dirancang untuk memperoleh persepsi beberapa masyarakat di kelurahan Bener Kecamatan Tegalrejo tentang hasil penelitian yang telah peneliti simpulkan apakah menjadi hal yang riil dan dapat dipercaya sehingga ke depannya hasil penelitian ini agar bisa menjadi masukan pemerintah Kota Yogyakarta dalam Upaya Pengelolaan Lingkungan Hidup (UKL) dan Upaya Pemantauan Lingkungan Hidup (UPL).

\section{Hasil dan Pembahasan}

Memelihara sapi dinilai merupakan hal yang menguntungkan untuk beberapa orang yang memang senang atau berminat di bidang peternakan, selain tidak hanya dapat menghasilkan daging dan susu, namun juga bernilai ekonomi yang tinggi ketika dijual (Muis, 2015). Selain daging dan susu, kotoran sapi juga dapat menghasilkan nilai ekonomi meskipun tidak seberapa besar keuntungannya. Keuntungan dari hasil penjualan pupuk organik kotoran sapi jika dinilai dengan nilai ekonomi sangat kecil, namun dilain sisi keuntungan yang lain dapat menambah kesuburan tanah pada lahan pertanian (Nugraha, Sudodo, \& Hutagalung, 2009). Pada penelitian ini 
berlokasi di Kota Yogyakarta, tepatnya di Kelurahan Bener Kecamatan Tegalrejo. Terdapat Kandang sapi yang unik di tengah-tengah permukiman kota, selain itu wilayah sekitar kandang tersebut terkenal dengan kawasan perumahan elit. Kandang sapi ini dikelola oleh Kelompok Kandang Tri Andini Rejo.

\subsection{Kondisi Fisik Kandang Sapi}

Dengan suasana perkotaan Yogyakarta namun kondisi lingkungan yang masih mencirikan suasana perdesaan yang masih kental terjaga di kalangan masyarakat. Lokasi yang ideal untuk membangun kandang adalah daerah yang letaknya cukup jauh dari pemukiman penduduk, biasanya berada di dekat lahan pertanian, di tengah sawah atau ladang (Nugraha et al., 2009). Kandang juga hendaknya mudah dicapai oleh kendaraan agar mudah dalam aksesnya (Steflyando, 2014). Selain itu kandang harus terpisah dari rumah tinggal dengan jarak minimal 50 meter (Sihombing, 2000). Hal ini yang tidak memenuhi syarat untuk Kandang sapi yang di kelola Kelompok kandang Tri Andini Rejo seperti yang terlihat pada gambar 1. Sehingga ada beberapa permasalahan lingkungan yang perlu dikaji agar penanganannya tidak berdampak ke lingkungan sekitarnya.

Suatu usaha dan atau kegiatan pasti mempunyai dampak bagi lingkungan sekitarnya. Adapun dampak positif dan negatif dari usaha dan atau kegiatan peternakan sapi yaitu (Suryahadi, Nugraha, Bey, \& Boer, 2000):

Dampak positif

1. Sarana jalan

Usaha dan atau kegiatan peternakan ini membuat pemerintah daerah ingin ikut serta dalam pembangunan daerahnya, maka pemerintah memperbaiki sarana jalan.

2. Fasilitas kesehatan
Fasilitas kesehatan ini diberikan secara berkala apakah terdapat penyakit yang serius akibat dari usaha dan atau kegiatan peternakan sapi.

3. Pariwisata

Peternakan sapi dibangun pada daerah yang masih asri, sehingga bagi warga sekitar yang ingin melihat dapat berwisata dan belajar mengenai peternakan tersebut.

4. Lapangan pekerjaan

Suatu usaha dan atau kegiatan yang dilakukan harus memiliki sumber daya manusia untuk mengelola usaha dan atau kegiatan tersebut. Oleh karena itu, peternakan sapi ini memilih warga sekitar sebagai pekerjanya.

Dampak negatif

1. Pencemaran udara

Polusi udara yang mengakibatkan terciumnya aroma tidak sedap dari limbah/kotoran sapi dan limbah sisasisa pakan.

2. Pencemaran tanah

Polusi tanah diakibatkan pula oleh kotoran cair sapi.

3. Pencemaran perairan

Polusi perairan diakibatkan oleh kotoran cair sapi yang masuk ke dalam badan air.

4. Kesehatan

Kesehatan diakibatkan oleh polusipolusi yang terjadi dan sebagai media untuk berkembang biaknya lalat, hewan seperti lalat ini yang lalu masuk ke rumah-rumah penduduk menyebarkan beberapa penyakit.

Menurut Wakil Ketua Kelompok Ternak Tri Andini Rejo yaitu Bapak Bambang, untuk lokasi pengembakbiakan Sapi Betina dinilai kurang sesuai, disebabkan karena letak Kandang yang dekat dengan Kali Code maka menyebabkan udara dingin dan Lembab. Sedangkan untuk pengembangbiakan Sapi betina dibutuhkan Kandang yang 
hangat, nyaman dan bersih. Selain itu juga ukuran kandang yang tidak cukup luas yaitu $100 \mathrm{~m}^{2}$ untuk Kandang sisi Utara dan $200 \mathrm{~m}^{2}$ untuk kandang sisi Selatan merupakan faktor utama dalam kegiatan pengembangbiakan. Ukuran kandang yang digunakan sebaiknya disesuaikan dengan jumlah sapi yang dipelihara dan perencanaan ke depannya. Kandang yang baik dan benar harus memenuhi beberapa persyaratan berikut ini (Fikar \& Ruhyadi, 2010).

\section{Letak dan Arah Kandang}

Menurut tata cara pembuatan kandang yang baik, disarankan untuk membangun kandang tunggal hendaknya menghadap ke timur. Sedangkan untuk kandang ganda, disarankan membujur dari utara ke selatan. Hal ini disebabkan karena untuk pencahayaan arah sinar matahari dan juga arah angin yang baik untuk pertukaran atau sirkulasi udara di dalam kandang. Pembuatan Kandang Sapi di Kelurahan Bener, Kecamatan Tegalrejo ini sudah sesuai dengan hal tersebut, yaitu kandang ganda yang membujur dari Utara ke Selatan.

\section{Ukuran Kandang}

Ukuran kandang harus disesuaikan dengan ukuran tubuh sapi dan jenis kandang yang digunakan. Pada umumnya, kebutuhan luas kandang sapi per ekor sekitar $1.5 \times 2.5 \mathrm{~m}, 1.5 \times 2 \mathrm{~m}$, atau 1 x $1.5 \mathrm{~m}$. Untuk Luas Kandang di Kelurahan Bener, Kecamatan Tegalrejo masih kurang luas untuk jumlah sapi yang ada pada waktu menerima bantuan sapi dari pemerintah Kota Yogyakarta sebanyak 50 ekor. Luas kandang yaitu 8 $\mathrm{m} \times 12.5 \mathrm{~m}$ untuk kandang di sisi Utara sedangkan kandang di sisi Selatan $10 \mathrm{~m} x$ 20 m memanjang dari Utara ke Selatan mengikuti arah kali Code. Karena kandang yang tidak mencukupi untuk menampung banyaknya sapi maka beberapa sapi terpaksa di jual dan beberapa ekor dibagi kepada anggota yang bersedia bertanggungjawab dan memiliki lahan untuk pemeliharaannya. Sehingga jumlah sapi yang ada di kandang kelompok hanya tersisa kurang lebih 15 ekor di kandang utara dan 20 ekor di kandang Selatan. Dengan hal tersebut dinilai syarat untuk kebutuhan luas kandang per ekor dapat terpenuhi.

\section{Konstruksi Kandang}

- Lantai

Lantai kandang sapi biasanya dibuat dari bahan semen atau tanah yang dipadatkan dan dibuat lebih tinggi dari lahan sekitarnya. Lantai bisa dialasi jerami, karpet, kayu datar, papan, atau serbuk gergaji. Pemberian alas bertujuan agar kaki dan tubuh sapi tidak terluka terkena lantai semen yang kasar. Pemberian alas juga membuat kaki dan tubuh sapi tidak mudah kotor serta tidak terserang kuman penyakit. Selain itu, lantai yang diberi alas juga menjadi tidak cepat rusak akibat tergerus kaki sapi. Lantai kandang harus kuat, tidak licin, dan dibuat dengan kemiringan 15 derajat ke arah selokan di belakang sapi untuk mempermudah penampungan kotoran sapi dan pakan yang jatuh. Untuk Kandang yang dikelola oleh Kelompok kandang Tri Andini Rejo di Kelurahan Bener ini dapat dikatakan belum memenuhi syarat, karena untuk lantai kandang meskipun terbuat dari semen namun tidak diberi alas seperti yang terlihat pada gambar 2 .

- Dinding

Dinding kandang tidak boleh tertutup seluruhnya, harus dibuat terbuka sebagian agar sirkulasi udara di dalam kandang lancar. Bahan yang digunakan sebagai dinding bisa berupa tembok beton, papan, kayu, bambu, dan bilik bambu. Dinding kandang hanya berupa tempat minum dan tempat pakan yang dibuat setinggi $0.5-1$ meter dari permukaan tanah. Kandang kelompok sudah memenuhi syarat untuk dinding kandang, selain itu juga dilengkapi dengan tempat minum dan tempat pakan ternak seperti yang terlihat pada Gambar 3. 


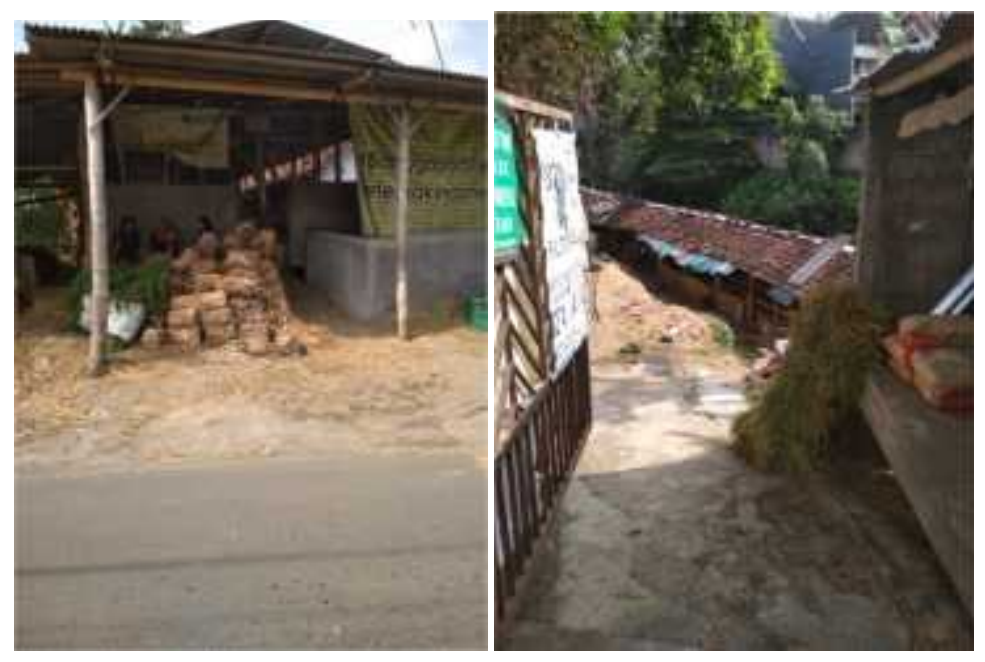

Gambar 1. Kondisi kandang Sapi

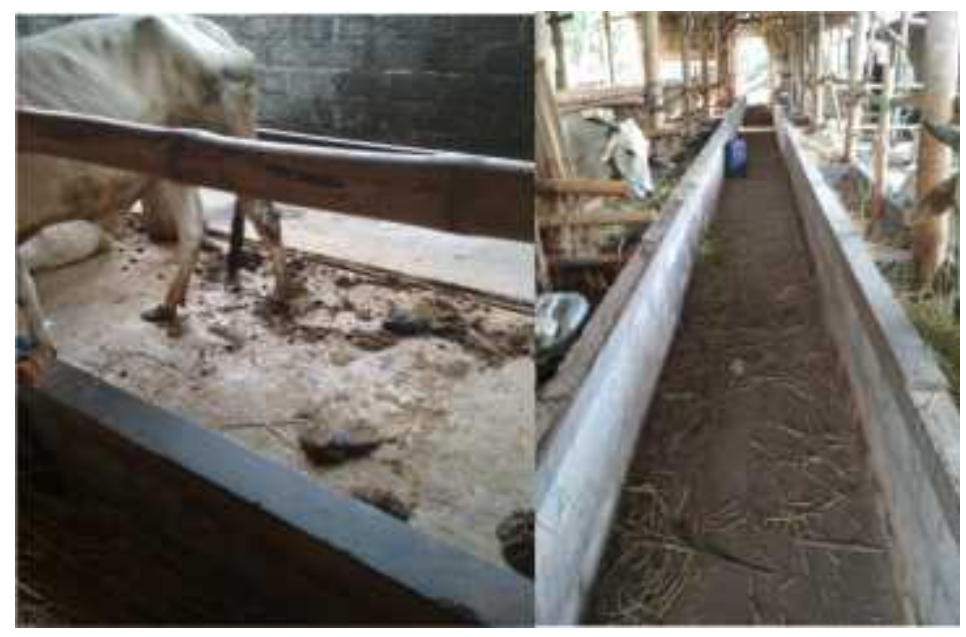

Gambar 2. Lantai Kandang Gambar 3. Dinding Kandang

- Atap

Atap kandang bisa terbuat dari bahan asbes, genting, rumbia, atau seng. Kandang untuk sapi potong bisa menggunakan atap dari asbes, karena sapi potong lebih tahan terhadap panas. Kandang sapi juga boleh tidak menggunakan atap alias terbuka. Kandang terbuka yang beratapkan langit ini biasanya digunakan untuk memelihara sapi bunting atau bakalan yang baru datang di peternakan. Kandang seperti ini membantu betina bunting untuk berlatih agar proses melahirkan bisa lancar.
Kandang Kelompok di Kelurahan Bener antara sisi Utara dan sisi Selatan memiliki perbedaan. Atap asbes untuk kandang di sisi utara, sedangkan atap campuran antara genting dan asbes untuk kandang di sisi selatan seperti yang terlihat pada gambar 4. Atap ini berfungsi agar Sapi dapat terlindung dari panas matahari dan guyuran hujan. Selain itu, Atap juga berfungsi menjaga Sapi dari suhu udara yang dingin agar tidak mudah terserang penyakit. 


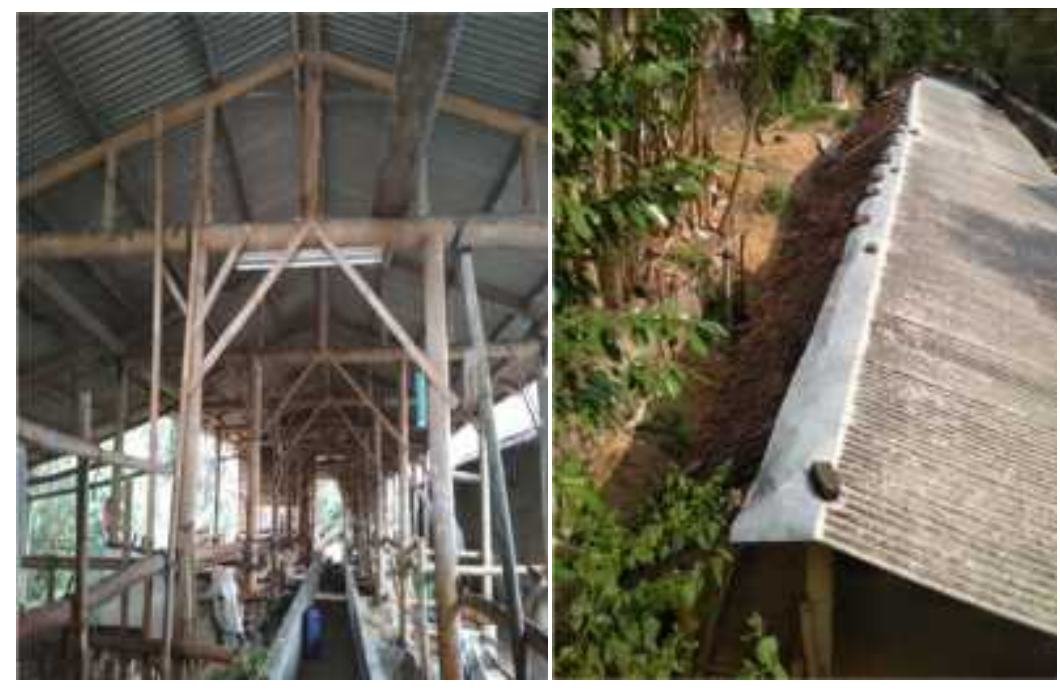

Gambar 4. Atap Kandang

- Lorong

Lorong di tengah kandang sebagai area lalu lintas peternak atau pekerja untuk memberi pakan atau minum sapi. Lorong ini biasanya berukuran 0.5-1 meter dan dibuat dari bahan semen. Lantai semen sebaiknya diberi corak garis-garis agar tidak licin. Kandang kelompok Tri Andini
Rejo sisi Utara juga memiliki lorong ditengah kandang untuk memudahkan pemberian pakan dan minum ternak, sedangkan sisi selatan karena berimpitan dengan sungai maka tidak diberi lorong, yaitu langsung di luar sisi kandang, karena kandang bentuknya yang memanjang seperti yang terlihat pada gambar 5 .

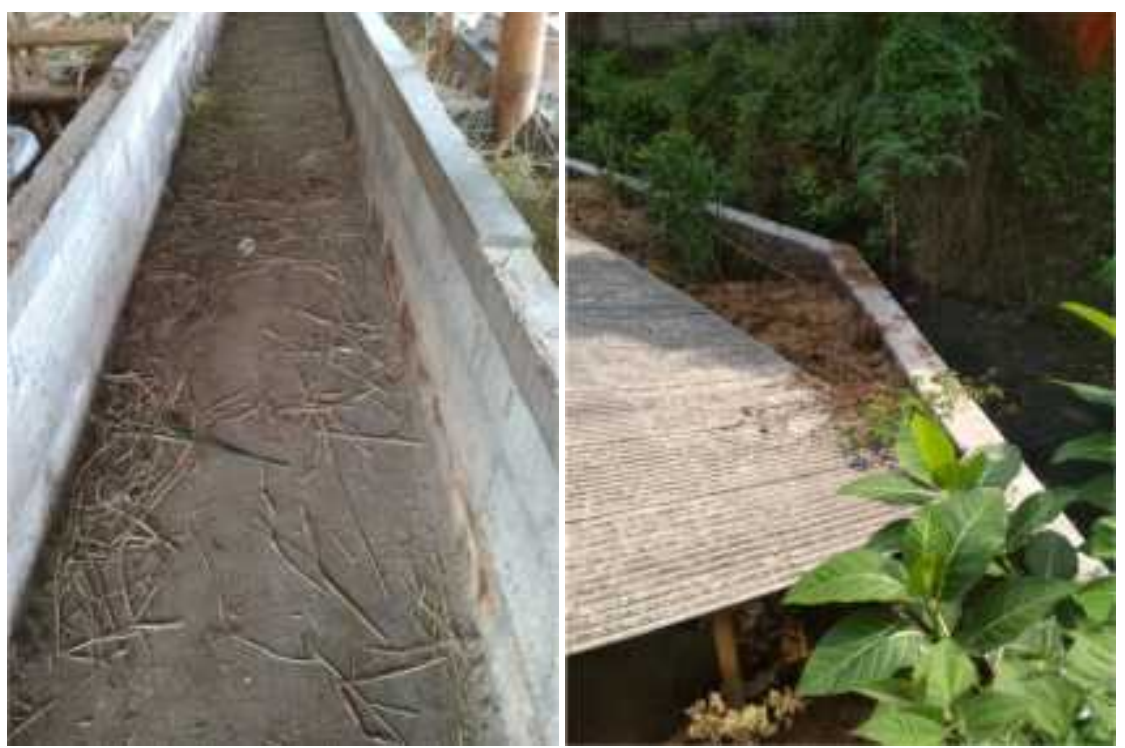

Gambar 5. Lorong Kandang

- Selokan

Selokan berfungsi sebagai tempat pembuangan kotoran. Selokan biasanya dibuat dengan lebar 20-30 $\mathrm{cm}$ dan kedalaman 10-20 cm. Selokan ini dibuat di dalam kandang di bagian ekor sapi, 
baik itu di kandang tunggal maupun kandang ganda. Tujuannya, agar anggota kelompok yang bertugas mudah membersihkan kotoran dan urine sapi seperti yang terlihat pada gambar 6 .

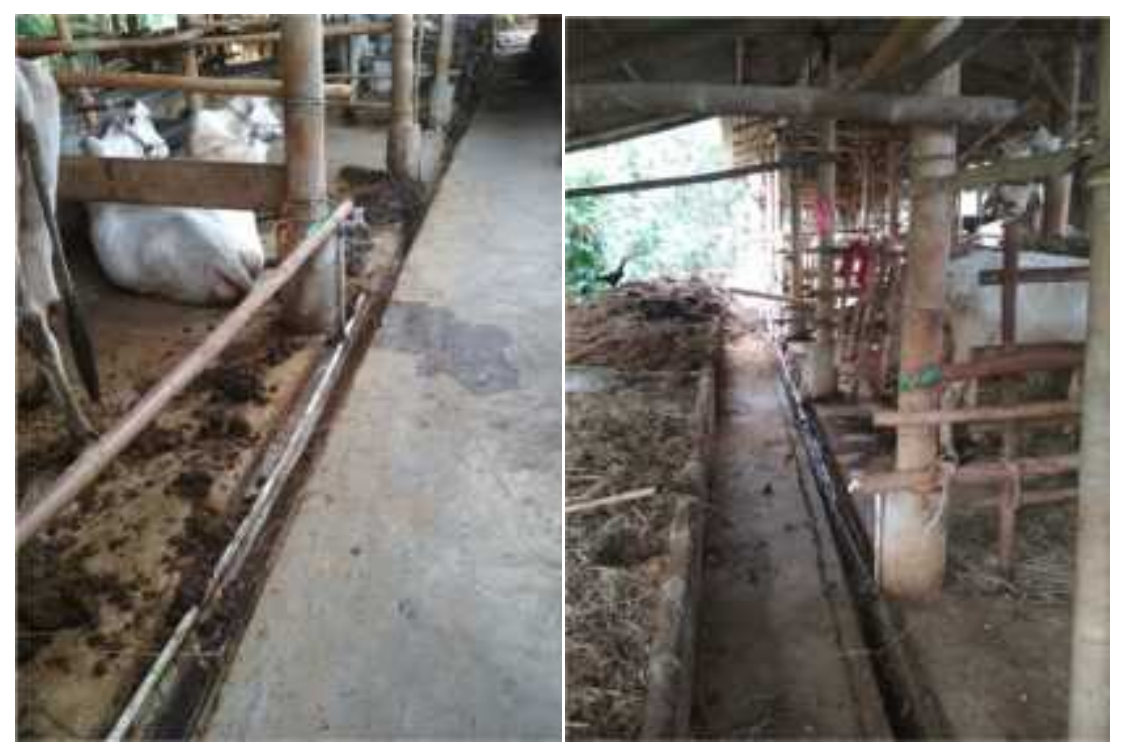

Gambar 6. Selokan Kandang

Bak Pakan dan Minum

Bak pakan dan bak air minum dibuat di depan kandang dengan perbandingan 2 : 1. Artinya, jika panjang bak pakan satu meter, maka panjang bak air minum setengah meter. Tempat pakan dan minum ini dibuat dari bahan semen atau papan kayu dengan dasar rapat agar pakan tidak mudah tercecer. Tempat minum tidak boleh bocor dan harus mudah dibersihkan.

\subsection{Pengelolaan Kandang Sapi}

Pengelolaan Kandang Sapi ini erat kaitannya dengan aktivitas yang dilakukan oleh pengelola kelompok kandang, baik kegiatan perawatan dan pemeliharaan sapi hingga pengelolaan limbah yang dihasilkan berupa kotoran sapi dan sisa pakan sapi. Pengelolaan limbah merupakan upaya dalam mengurangi resiko terhadap lingkungan dimana terjadi pencemaran atau perusakan lingkungan hidup.

Kelompok kandang Tri Andini Rejo yang berlokasi di Kelurahan Bener Kecamatan Tegalrejo sudah mulai mengubah kotoran sapi menjadi pupuk kompos sejak tahun 1985. Awal mula kotoran sapi dan urin sapi dikumpulkan dan di diamkan hingga menjadi pupuk, setelah cukup lama hampir 3 bulan baru siap untuk dijual.

Setelah itu ada bantuan alat BIOGAS yang diberikan oleh pemerintah yang digunakan untuk mengolah kotoran sapi menjadi bahan bakar. Dengan alat Biogas yang dipasang untuk pengolahan limbah ini maka beberapa masyarakat dapat merasakan manfaatnya. Meskipun tidak banyak masyarakat yang merasakan manfaatnya namun hal ini cukup menghemat bahan bakar karena alat ini dapat disalurkan ke beberapa rumah yang terletak di sekitar lokasi kandang.

Namun hal ini tidak berjalan cukup lama disebabkan karena kurangnya sumberdaya manusia untuk mengoperasikan alat tersebut. Lalu pada Tahun 2016 mulai diadakan pelatihan "Pengawetan pakan melalui pakan fermentasi dan Pembuatan pupuk kompos" di Kelompok Tri handini Rejo, Bener, Tegalrejo. Pelatihan tersebut diikuti oleh hampir semua anggota kelompok 
secara bersama-sama. Setelah kegiatan pelatihan tersebut pengelolaan mulai beralih ke pengumpulan kotoran sapi dengan pengolahan menjadi pupuk kompos yang berkualitas. Limbah padat yang berubah menjadi kompos nilai nya lebih mahal daripada yang dijual begitu saja yaitu Rp250.000 sampai dengan Rp300.000 per Truk. Untuk limbah cair tidak di olah, dibiarkan begitu saja. Dahulu sempat ada yang menampung dengan harga jual Rp7.000 per liter. Namun harga terbilang rendah sehingga untuk saat ini tidak ada yang mau untuk mengumpulkan. Hasil dari pelatihan tersebut sampai sekarang masih dilakukan. Untuk mengolah kotoran sapi menjadi pupuk kompos dibutuhkan beberapa bahan yaitu yang pertama Kotoran sapi kurang lebih dengan berat 1 ton, kotoran ini sebaiknya yang tidak banyak mengandung air bahkan lebih baik yang sudah kering. Bak Pengkomposan (Gambar 7). Dekomposer secukupnya, bisa berbagai merk yang dijual di toko pertanian. Jerami yang berfungsi untuk mengontrol kadar air jika pupuk terlalu banyak mengandung air atau terlalu basah. Kapur dolomit yang mengandung unsur hara Kalsium dan Magnesium membantu meningkatkan kualitas pupuk kompos yang dihasilkan nanti karena dapat membantu menetralkan $\mathrm{Ph}$ Tanah sehingga tanah menjadi lebih subur dan dapat meningkatkan produksi tanaman. Urea yang mengandung Nitrogen, seperti kapur dolomit tadi akan membantu meningkatkan kualitas pupuk kompos yang akan dihasilkan karena dapat memperbaiki sifat kimia tanah yang terkait dengan ketersediaan nitrogen dalam menunjang pertumbuhan tanaman.

Pembuatan pupuk kompos ini ada beberapa tahap yang harus dilakukan, yang pertama kotoran sapi di kumpulkan dalam bak lalu diatasnya diberi jerami, kapur dolomite, urea, dan dekomposer. Yang kedua ulangi lagi hingga berlapislapis, kemudian diatasnya ditutup dengan terpal kurang lebih selama 3 sampai 4 minggu. Setiap minggu nya dibalik dengan cangkul.

Setelah kotoran sapi diproses menjadi pupuk yang telah siap atau matang, lalu di tempatkan dalam bagor atau karung, hal ini berfungsi untuk memudahkan dalam pengangkutan dan pemasarannya. Pemasaran Pupuk ini menurut wakil ketua kelompok kandang tidak mengalami kesulitan karena sudah memiliki konsumen atau pelanggan tetap. Beberapa konsumen datang dari beberapa wilayah yaitu dari Bantul DIY, bahkan ada juga yang berasal dari Temanggung.

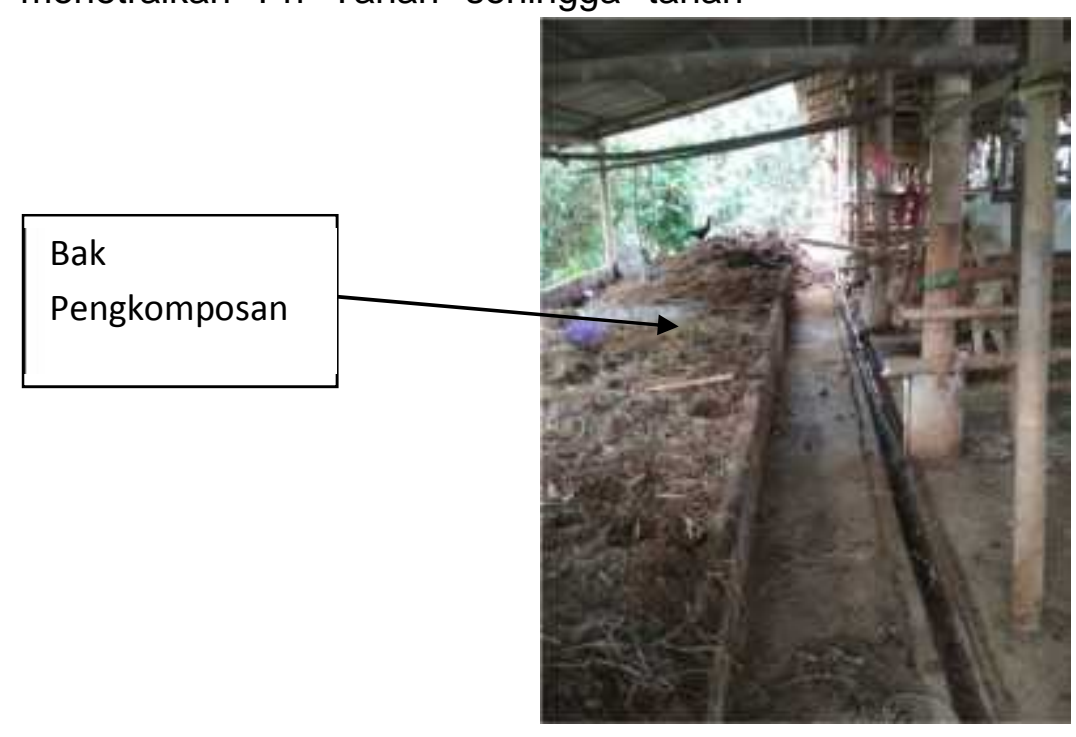


Kegiatan bila tidak memiliki kendala pastilah merupakan hal yang janggal, beberapa kendala di hadapi oleh kelompok kandang Tri Andini Redjo. Bantuan alat Biogas ini memang sesuatu hal yang dinilai memiliki manfaat yang besar. Apalagi alat Biogas ini merupakan salah satu temuan bidang IImu dan Teknologi yang kedepannya dapat menjadi terobosan dalam penghematan energi listrik dan bahan bakar. Pemanfaatan dari hasil keluaran alat Biogas ini sudah menjadi perbincangan dan pengkajian berbagai ilmu akan penggantian BBM dan Listrik. Namun, alat yang modern jika tidak di imbangi dengan kualitas sumber daya manusia maka menjadikan masalah tersendiri dalam mengoperasikannya. Hal ini lah yang dihadapi oleh pengelola Kandang Tri Andini Redjo, alat Biogas memang tersedia namun terkendala SDM yang menangani atau merawat dan juga yang mengoperasikan alat Biogas tersebut. Menurut wakil ketua pengelola kelompok kandang masalah timbul dengan beberapa keluhan dari anggota dengan alasan karena alat biogas tersebut harus di pantau terus seberapa kadar air dan sebagainya dalam pengoperasiannya. Sehingga hal tersebut terbilang repot bagi anggota kelompok kandang yang notabene sekarang pekerjaan ini adalah pekerjaan sampingan ataupun hanya sekedar menjadi hobby atau hiburan atau terbilang tidak mampu dilakukan karena pendidikan dan pengetahuan yang kurang, bagi anggota yang sudah lanjut mengeluhkan bahwa hal ini membuang waktu disebabkan masih banyak aktifitas yang harus dilakukan seperti mencari pakan sapi dan sebagainya. Maka untuk mengurus dan mengelola alat biogas di kelompok Kandang Tri Andini Redjo tidak ada yang sanggup dan bersedia, sehingga alat tersebut terbengkalai tidak difungsikan.

Selain alat Biogas yang terbengkalai tidak difungsikan, permasalahan yang lain adalah kurangnya alat kebersihan yang digunakan. Misalnya alat yang digunakan untuk mengumpulkan dan mengangkut limbah padat ke bak pengkomposan hanya ada satu, dan itu digunakan berulang kali jarang untuk dibersihkan atau dicuci, sehingga dinilai dari segi kebersihan sangat kurang.

\subsection{Persepsi Masyarakat Terhadap Lingkungan Kandang Sapi}

Kandang di Kelurahan Bener, Kecamatan Tegalrejo, Kota Yogyakarta. sudah dibangun sejak tahun 1985. Sejak itu pula langsung dibentuk kelompok Ternak Tri Andini Rejo dengan anggota kelompok pertama kali 42 Orang. Kandang didirikan di tanah wedi kengser Kali Code yaitu tepat di pinggir Kali Code. Dahulu lokasi di sekitar kandang belum seperti sekarang ini yang penuh dengan perumahan dan permukiman warga. Kandang berada di tengah-tengah persawahan yang luas, bahkan jalan Godean tampak jika dilihat dari kandang. Namun perkembangan kota mulai bergeser, awal mula tanah di pinggir jalan dibeli oleh warga Negara asing, lambat laun mulai menjalar ke dalam. Sehingga kondisi lambat laun berubah menjadi permukiman elit seperti sekarang ini. Agar Kandang tidak tergeser maka pengelola kandang menggunakan berbagai macam penyiasatan, hal ini guna mempertahankan kegiatan beternak sapi. Tentunya hal ini menjadi pemandangan yang unik di tengah perkotaan terdapat kegiatan beternak sapi. Maka pada Tahun 2012, Kelompok Ternak Tri Andini Rejo mengikuti program pemerintah yaitu program penyelamatan sapi betina produktif yang disalurkan melalui Dinas 
Sosial Daerah Istimewa Yogyakarta yang menerima bantuan sebesar Rp500.000.000 yang langsung di wujudkan menjadi 50 ekor sapi oleh kelompok dan berhasil dikembangbiakkan menjadi 80 ekor, lalu sejumlah 30 ekor telah terjual.

Limbah sapi bila dibiarkan saja maka akan timbul beberapa masalah dan juga persepsi masyarakat sekitarnya. Selain dapat mengganggu kesehatan ternak dan lingkungannya juga mengganggu kenyamanan bertempat tinggal mengingat lokasi kandang yang berada di tengatengah permukiman masyarakat. Oleh karena itu, perlu cara yang tepat agar kotoran sapi ini dapat menghasilkan nilai ekonomi. Pengolahan kotoran ternak menjadi pupuk yang berkualitas.

Persepsi mayoritas Masyarakat pada umumnya yang bertempat tinggal pada radius kurang dari 50 meter dari kandang memang mengatakan bahwa sepanjang hari mencium bau yang tidak sedap. Namun hal ini, telah dirasakan oleh seorang warga yang tinggal selama 13 Tahun menyatakan persepsi yang berbeda, yaitu merupakan kondisi yang biasa, oleh sebab itu bau yang tidak sedap ini sudah bukan merupakan gangguan lagi bagi beliau. Sedangkan ada beberapa di Permukiman Elit sebelah Barat lokasi Kandang mengatakan bahwa bau yang tidak sedap cukup dikurangi dengan menutup beberapa ventilasi rumah rapat-rapat, untuk sirkulasi udara di dalam rumah mereka cenderung menggunakan AC.

Untuk Udara sudah menjadi hal yang lumrah dan ada yang menggunakan masker atau ditutup ventilasi rumahnya. Masing-masing sudah memiliki kiat tersendiri untuk beradaptasi dengan lingkungan tempat tinggalnya. Hal ini membuktikan bahwa masih adanya rasa toleransi yang dipupuk di kalangan masyarakat Kelurahan Bener.
Sedangkan untuk Tanah dan Air, warga sekitar lokasi kandang tidak merasakan atau mengeluhkan adanya pencemaran yang diakibatkan oleh aktifitas kandang. Bahkan sebagian besar masyarakat lebih memilih untuk menggunakan air sumur daripada air dari PDAM. Air sumur yang masyarakat konsumsi juga jernih, tidak berbau dan juga tidak berwarna.

Faktor yang mempengaruhi persepsi masyarakat adalah tingkat pengetahuan masyarakat terhadap lingkungannya, dimana tingkat pengetahuan ini menentukan sikap yang diambil oleh masyarakat dalam menyikapi adanya kandang kelompok di lingkungan rumahnya. Persepsi masyarakat yaitu suatu tanggapan, pandangan, dan penilaian tentang lingkungannya baik itu menyangkut udara, air dan tanah. Masyarakat mengemukakan perasaan senang atau tidak senang, setuju atau tidak setuju terhadap keberadaan kandang sapi di tengah-tengah permukiman.

\subsection{Upaya Pemantauan Lingkungan}

Upaya pemantauan lingkungan tidak lepas kaitannya dengan Analisis Mengenai Dampak Lingkungan atau biasa disebut AMDAL. Suatu kegiatan pasti akan dinilai dari segi lingkungannya, dan hal tersebut berkaitan dengan kualitas lingkungan. Tujuan AMDAL ini digunakan untuk menjaga, meningkatkan kualitas lingkungan dan memperkecil jumlah pencemaran lingkungan, selain itu juga dapat memberikan masukan untuk penyusunan rencana pengelolaan dan pemantauan lingkungan hidup dan memberikan informasi kepada masyarakat yang tinggal di lokasi sekitar kandang sapi atas dampak yang ditimbulkan dari aktifitas kandang kelompok tersebut. Kegiatan kandang kelompok Tri Andini Redjo diketahui tidak ada kerusakan lingkungan yang ditimbulkan baik itu pembuangan limbah yang tidak memenuhi 
persyaratan teknis dan kesehatan, dan pengelolaan yang mengabaikan daya dukung dan daya tampung lingkungan. Hal ini terbukti dari persepsi masyarakat yang tinggal di sekitar lokasi kandang tidak mengeluhkan adanya penurunan lingkungan dari segi tanah dan sumber air. Pencemaran udara juga terbilang kecil, hal ini dibuktikan dengan masih bisa di antisipasi oleh masyarakat dengan beberapa kiat tertentu. Selain itu, lingkungan yang terbilang masih asri dengan masih adanya sawah dan beberapa pohon maka dapat berfungsi dalam mengurangi bau yang tidak sedap.

Kegiatan pengelolaan Kandang sapi merupakan kegiatan dengan kriteria bebas AMDAL, namun meskipun bebas AMDAL maka tetap harus ada Upaya Pengelolaan Lingkungan Hidup (UKL) dan Upaya Pemantauan Lingkungan Hidup (UPL). UKL dan UPL ini hendaknya dilakukan oleh penanggung jawab kandang sapi yaitu pengelola kandang sapi dimana kegiatan ini adalah melaporkan kegiatan pengelolaan dan pemantauan lingkungan hidup agar lingkungan tetap terjaga kualitasnya dengan aktifitas yang dilakukan oleh pengelola kandang beserta seluruh anggota kelompok kandang Tri Andini Redjo. Berikut adalah gambar skema dari prosedur pelaksanaan AMDAL (Gambar 8).

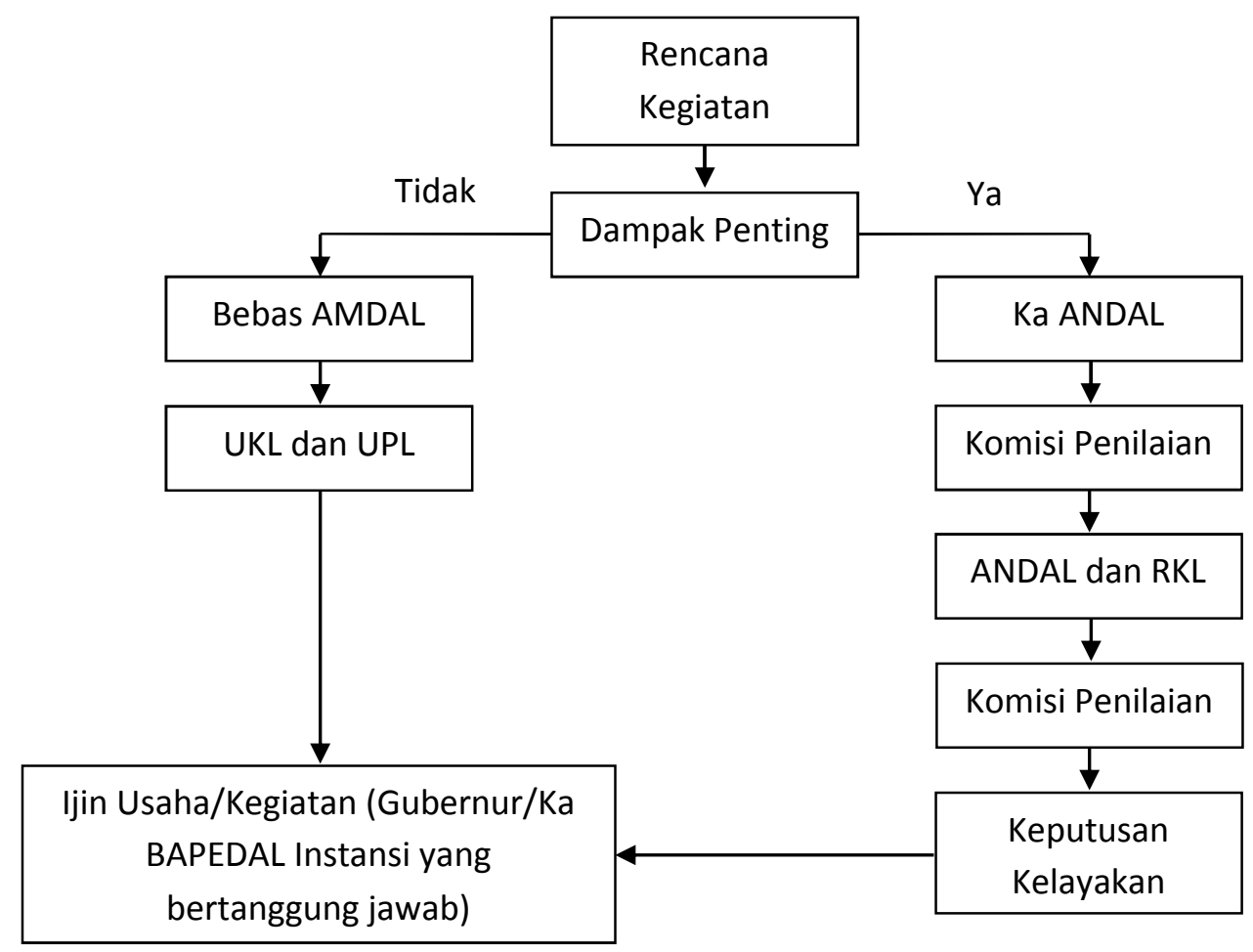

Gambar 8. Skema Prosedur Pelaksanaan AMDAL

\section{Penutup}

1. Persepsi masyarakat yang tinggal di sekitar lokasi kandang sapi yang dikelola oleh kelompok kandang Tri Andini Rejo memiliki respon netral, hal ini ditunjukkan dengan sikap masyarakat yang biasa saja dengan keberadaan kandang. Masyarakat Kelurahan Bener mengedepankan rasa toleransi yang tinggi, meskipun terganggu dengan bau yang tidak sedap namun dapat disikapi dengan cara masing-masing.

2. Pengelolaan Limbah yang selama ini dilakukan oleh pengelola kandang memiliki pergeseran dari yang semula hanya menumpuk kotoran sapi kemudian di jual, sekarang diproses menjadi pupuk organik yang berkualitas dan bernilai 
ekonomi tinggi. Pengelolaan Limbah dengan menggunakan teknologi yang maju belum termanfaatkan dengan baik oleh pengelola kandang karena kurangnya kualitas Sumberdaya Manusia. Namun dengan kajian ini diharapkan pengelola kandang dapat melakukan perbaikan atau meminimalisir dampak bau yang ditimbulkan dan mengadakan pelatihan dalam rangka peningkatan kualitas Sumberdaya Manusia.

\section{Daftar Pustaka}

Arikunto, S. (2006). Prosedur Penelitian Suatu Pendekatan Praktik. Jakarta: Rineka Cipta.

Ariola, M. (2006). Principles and Methods of Research' 2006 Ed. Manila: Rex Book Store.

Fikar, S., \& Ruhyadi, D. (2010). Buku Pintar Beternak \& Bisnis Sapi Potong. Yogyakarta: Agromedia Pustaka.

Luthfi, A., \& Wijaya, A. (2011). Persepsi Masyarakat Sekaran Tentang Konservasi Lingkungan. Journal Komunitas, 3(1), 29-39.

Muis, J. M. (2015). Kinerja dan Prospek Pengembangan Usaha Ternak Sapi Potong Ramah Lingkungan di Sumatera Barat. Journal Widyariset, 18(1), 5970.

Nugraha, K. H., Sudodo, \& Hutagalung, R. A. (2009). Hubungan Antara Persepsi Masyarakat tentang Ruang Terbuka Hijau dan Etika Lingkungan dengan Partisipasi Masyarakat dalam Pengembangan Kota yang Berwawasan Lingkungan. Jurnal Lingkungan Hidup, 1(1), 1-12.

Sihombing, D. T. H. (2000). Teknik Pengolahan Limbah Kegiatan/Usaha Peternakan. Pusat Penelitian Lingkungan Hidup Lembaga Penelitian Institut Pertanian Bogor.

Soesanto. (2003). Persepsi Masyarakat Terhadap Lingkungan Permukimannya di DAS Brantas. Journal MINTAKAT, 2(1), 1-8.

Steflyando, R. (2014). Analisis Kelayakan Usaha Sapi Potong Dengan Metode Zero Waste Farming di Kecamatan
Parongpong. Journal Institut Teknologi Nasional, 1(4), 226-237.

Sugiyono. (2007). Metode Penelitian Kualitatif dan Kuantitatif. $R \& D$. Bandung: Alfabeta.

Sujarweni, W. (2014). SPSS Untuk Penelitian. Yogyakarta: Pustaka Baru Press.

Suryahadi, Nugraha, A. R., Bey, A., \& Boer, R. (2000). Laju Konversi Metan Dan Factor Emisi Metan Pada Kerbau Yang Diberi Ragi Tape Lokal Yang Berbeda Kadarnya Yang Mengandung Saccharomyces Cerevisiae. In Seminar Program Pascasarjana IPB. 